\title{
International Financial Reporting Standards Adoption and Value Relevance of Financial Information of Quoted Healthcare Firms in Nigeria
}

\author{
Taibat A. Atoyebi ${ }^{1}$, Yinka M. Salaudeen ${ }^{1} \&$ Jerry Y. A. Onyilokwu ${ }^{1}$ \\ ${ }^{1}$ Department of Accounting, Faculty of Management Sciences, University of Abuja, Nigeria \\ Correspondence: Taibat A. Atoyebi, Department of Accounting, Faculty of Management Sciences, University of Abuja, \\ FCT Abuja, Nigeria.
}

Received: June 5, 2018

Accepted: June 29, $2018 \quad$ Available online: July 1, 2018

doi:10.11114/aef.v5i4.3399

URL: https://doi.org/10.11114/aef.v5i4.3399

\begin{abstract}
International Financial Reporting Standards (IFRS) was first adopted in 2005 by European Union countries while Nigeria mandatorily adopted in 2012 to participate in opportunities offered by globalization. This study, therefore, investigated the impact of IFRS adoption on the value relevance of financial information of quoted Healthcare Firms in Nigeria. The study conducted a pre (2008-2011) and post (2012-2015) IFRS analyses on six Healthcare firms quoted on the Nigeria Stock Exchange. The study sourced data on Earnings per Share (EPS), Change in Earnings per Share (CEPS), Book Value per Share (BVPS) and Share Price (SP) from published annual reports of the quoted Healthcare firms and Cashcraft Asset Management. Using the Multiple regression model the study revealed that Pre- IFRS financial information is value relevant; Post-IFRS financial information is also value relevant; and Post-IFRS financial information has relative value relevance over Pre- IFRS financial information.
\end{abstract}

Keywords: international financial reporting standards, adoption, value relevance, financial information, healthcare firms

\section{Introduction}

The primary function of accounting is the provision of information necessary for evaluation of past business decision, which consists of current operating profit and realizable cost saving (Edward \& Bell, 1961). The value of accounting information which is affected by a number of factors is expressed by how effectively it meets the needs of users. The role accounting plays in an organization cannot be overemphasized as it involves the measurement and provision of accurate financial information to managers, investors, tax authorities, and other stakeholders to help them make informed decisions about how to allocate resources of the organization. Investors are not in a position to directly assess the performance of the company in which they intend to invest as they usually depend on financial statements (accounting reports) prepared by the management of the company.

Ikpefan \& Akande (2012) affirmed that accounting is business language while financial reporting is for communicating the business results, and they are both regulated by Generally Accepted Accounting Practices (GAAP) which are usually country based. The Nigerian GAAP (NGAAP) like in other countries has a unique characteristic that has been a subject of argument which is the historical cost accounting, which could be deceptive in decision making especially during the period of inflation as it misrepresents firms real position at that specific point in time (Kirkulak \& Balsari, 2009). Historical cost information has the potency of distorting, though not significantly, the accounting information provided to decision makers (Fodio \& Salaudeen, 2012). On another hand, financial reporting inconsistencies have persisted due to different reporting standards and requirements in different countries which poses challenges to international investors.

In 2005, The International Accounting Standard Board launched International Financial Reporting Standards (IFRS) for adoption, and the European Union countries had voluntarily adopted at that time. The threshold of IFRS led to the use of an array of definitions for contents of financial statements like assets, liabilities, equity, income and expenses. It has also given rise to the use of different criteria for the recognizing and measuring items in the financial statements. The shift to IFRS signifies a substantial switch in recognition and measurement of accounting numbers and it is reasonable to believe that adoption of IFRS will affect the quality of accounting numbers. Fair value measurement has been perceived to be one of the most prominent changes in IFRS as Agostino, Drago \& Silipo (2011) stated that one critical 
element is that IFRS rely heavily on fair value accounting as opposed to the concept of historical cost. However, the use of fair value in financial reporting should be with great caution based on the argument of implausible numbers, particularly when exclusive assets and liabilities are measured based on subjective assumption.

Khanagha (2011) stated that the value and quality of accounting information are ascertained by how well it meets the requirements of users and the study of value relevance is the assessment of the relationship that exists between accounting information and capital market figures. IFRS brought about changes in definition, measurement, recognition of income, intangibles and the use of fair value judgment. Consequently, IFRS affects the reported accounting figures of earnings and book value of an organization. Therefore, it becomes imperative to investigate if accounting information as presented in financial statements are reflected in the stock price of companies in Nigeria.

The Nigerian healthcare industry is an aggregation and integration of sectors within the Nigerian economic system that offer goods and services to treat patients with curative, preventive, rehabilitative, and palliative care. Healthcare sector includes pharmaceutical firms, Hospitals, Biotechnology and Medical Technology firms. The healthcare industry has contributed to enhancing the growth of GDP of different countries, for example, Onisanwa (2014) affirmed that health indicators positively influence GDP in the long run. The healthcare sector is characterized by their substantial research and development spending for medical and biotechnology innovations, drugs discovery, formulation, development and licensing and faced with variety of potential threats such as burdensome litigation, political influence and lobbying, non-approval of new products, introduction of new therapies that are clinically and economically better than the existing alternatives by competitors. Since IFRS represents a substantial change in recognition and measurement of accounting numbers, the definition of some assets, liabilities and equity have changed for healthcare firms, and they all give a signal of change in the degree of value relevance of financial information. This study, therefore, examined the impact of IFRS adoption on the value relevance of accounting information which involves making clear the impact of IFRS on earnings, change in earnings and book values of healthcare firms in Nigeria and how that impact promotes value relevance of information provided by quoted healthcare firms in Nigeria.

\subsection{Statement of the Problem}

Value relevance of accounting information has always been a subject of academic debate. It is of interest to standard setters, investors and researchers since it empirically proves the reflection of accounting information in share prices of firms. Although there have been studies on the value relevance of GAAP financial information, the results have been inconsistent until the hit of the capital market crash and the Enron's case. The capital market crash, economic meltdown and the Enron's case revealed that firms that were proved to be profit-making became insolvent and as such pose a big question as to whether reporting under GAAP is value relevant. The aftermath of the global economic crises, the accounting profession, arose to the need of providing value relevant information by introducing a single set of the accounting standard for global use called IFRS. Empirical works on value relevance and IFRS adoption from different countries and even developed capital markets have produced mixed results. Some researches such as Yahaya, Onyabe \& Usman (2015); Umoren \& Enang (2015); Alfaraih \& Alanezi (2011); Arum (2013); Lee, Walker \& Zeng (2013); Suadiye (2012); Khanagha (2011); Zeng, Guo, Yan, \& Xiong (2012); Chebaane \& Othman (2014); and Kargin (2013) concluded that IFRS financial information are value relevant. While other such as Outa (2011); Clarkson, Hanna, Richardson \& Thompson (2011); Kousernidis \& Ladas (2010); and Paananen \& Lin (2009) concluded that IFRS financial information is not value relevant. Kaaya (2015) opined that the question as to whether IFRS improves value relevance of book value of equity and earnings is still a controversial and an open casement for scrutiny.

It has also been realized that empirical studies in Nigeria on IFRS adoption and value relevance are scantily in existence with very few studies in the healthcare industry to the best of the researcher's knowledge at the time of this research even though healthcare sector is vital to Nigeria economy. There is sparse empirical research to identify the effect of accounting standards reforms on the value relevance of accounting information in Nigeria (Yahaya, Onyabe \& Usman 2015). The significant change that accompanied IFRS is the use of fair value measurement as against historical cost measurement. Furthermore, with particular concern to the healthcare industry, IFRS has influenced definition, recognition and measurement of intangible assets. This change has a direct effect on the earnings and book value of firm since intangibles that were capitalized under GAAP are now being expensed in IFRS, e.g. research and development cost internal to the firm. Also, intangibles are not capitalized under IFRS unless it has a direct flowing financial benefit. This development gives rise to a need to examine if earnings and book value has improved value relevance.

Mixed result in value relevance researches; lack of consensus among researchers on value relevance of IFRS Financial information; the interest of standard setters who are interested in the best reporting standard; IFRS as a recent phenomenon; argument against fair value measurement; sparse research in Nigeria on IFRS; and fundamental changes in measurement, recognition, classification and definition of assets and liabilities are the underlying issues that ignited this study. This study examined the impact of IFRS adoption on the value relevance of financial information of quoted healthcare firms in Nigeria. The following hypotheses are formulated to achieve the objectives of this study: 
$\mathbf{H}_{01}$ : Pre IFRS financial information has no significant value relevance in the Nigerian healthcare firms.

$\mathbf{H}_{\mathbf{0 2}}$ : Post IFRS financial information has no significant value relevance in the Nigerian healthcare firms.

$\mathbf{H}_{\mathbf{0 3}}$ : There is no significant difference between the value relevance of accounting information of the pre and post IFRS adoption in the healthcare firms in Nigeria.

\section{Materials Studied}

\subsection{The Concept Value Relevance}

The construct "value relevance" over the years has been defined by researchers and scholar judging from their experiences. Value relevance is commonly used as a construct and proxy for accounting quality (Kaaya, 2015). It is measured as the statistical association between financial statement figures and stock market values (Suadiye, 2012). While Beisland (2009) and Francis \& Schipper (1999) concisely defined value relevance as the ability of financial information to capture and summarize firm value and also as a statistical association between financial statement information and stock market values.

Value relevance approach can be used to assess the usefulness of accounting information to stockholders. However, to assess value relevance, it is essential to determine how accounting information records are reflected in stock prices. In confirmation, Barth, Beaver and Landsman (2001); Keener (2011) and Khanagha (2011) viewed value relevance as the association between accounting amounts and security market values. However, Barth et al. (2001) further stated that value relevance suggests testing whether accounting amounts explain the cross-sectional variation in share prices.

\subsection{International Financial Reporting Standards}

IFRS are set of guidelines and laid down rules set by the International Accounting Standard Board (IASB) for use in the compilation of financial statements. With the advent of globalization, the world capital market has witnessed rapid expansion, diversification and integration which have brought about a shift away from local reporting standards to global standards. In 2005 European Union commission issued legislation to require the use of IASB standards for all listed firms thereby making IFRS mandatory. In response to this, about a hundred and twenty countries have adopted IFRS with Nigeria inclusive. In line with development in other countries and jurisdictions, Nigeria had signaled its willingness to adopt the IFRS in 2012. Some items in the financial statement have been altered in IFRS either by a change in its definition, classification or measurement. Some of these items that have been affected thus: debt \& equity investments, consolidation, transfer of financial assets, provisions, business combinations, share-based compensation, pensions, taxation, loans, derivatives, own shares and bonds, capitalization of software, netting fixed assets, real estate investment, impairment and foreign currency.

\subsection{Financial Information: Book Value and Earnings}

The financial statement presented in corporate reporting contains information needed by users of the financial statement. These users have interest in different accounting number as it affects their decision making. Basically, for those investors who are interested in firm value are concerned with earnings, dividend and book value of a firm. However, not all information is used in the decision-making process as only information that is both relevant and reliable will influence market values. Earnings per share (EPS) changes have a significant influence on stock prices in the long run. Stock prices increase when company profits grow, and decrease when company profits decline. EPS is one of many things that can be used as a basis for determining an "intrinsic value" for a stock. The book value of a company is an assessment of the value of the net asset of a company or the accountant's measure of what the equity of a firm is worth. Therefore, book value per share is assets less liability divided by the number of shares outstanding. Burgtahler and Dichev (1997) observed that the extent of association with earnings and book value is dependent on the level of success of a firm because when a firm is successful earnings act more as an essential determinant of equity value while when the firm is unsuccessful book value becomes an important determinant of equity value.

\subsection{GAAP Financial Information and Value Relevance}

Talebnia, Valipour and Askari (2012) reviewed the effects of free cash flow agency problems on the value relevance of earning per share and the book value per share using the stock price of chemical industry and pharmaceutical companies listed in the Tehran Stock Exchange from 2002 to 2011. Regression analyses were used and found a reduction in value relevance of earnings per share and book value per share. Chang, Chen, Su and Chang (2008) investigated the relationship between stock prices and earning per share (EPS) and also whether stock price responds to EPS under different levels of growth rate of operating revenue. Data were collected from 75 firms listed in Taiwan stock exchange from 1997 to 2006 and analyzed using the co-integration method. The empirical result indicated that the co-integration relationship existed between stock prices and EPS in the long-run and that for firms with a high level of growth rate, EPS has less power in explaining the stock prices; however, for the firm with a low level of growth rate, EPS has a substantial impact in stock price. Alfaraih and Alanezi (2011) explored the value relevance of accounting earnings and 
book value information produced by using firms listed on the Kuwait Stock Exchange (KSE) from 1995-2006. Two valuation models - price and returns were employed, and the results of both models showed that earnings and book value were both positively and significantly related to stock price and stock returns. It was also found that the value relevance of earnings and book value of KSE listed firms were higher than the findings observed in some developed and emerging countries.

Khanagha, Mohamad, Hasan and Sori (2011) examined the value relevance of accounting information in Iran for the period 1996 - 2008, before and after the codification of national accounting standard in 2001, their findings from a combination of regression and portfolio approaches, revealed that accounting information in Iran is value relevant, and the value relevance of Earnings per Share (EPS) is higher than book value of equity per share (BVPS). Mamuda (2015) investigated the value relevance of accounting information in the Nigerian listed conglomerate firms for the period 2007-2011. The study was based on the Ohlson model and multiple regression is employed as a tool of analysis and a total of eight firms that are listed on the Nigerian stock exchange under conglomerate were used for the study. The result showed that accounting information published by listed conglomerate firms in Nigeria has high value relevance to the investors in making investment decisions on the firms. Specifically, earnings has more value relevance than book value.

\subsection{IFRS Adoption and Value Relevance of Accounting Information}

Yahaya, Onyabe and Usman (2015) examined post-IFRS adoption value relevance of accounting information of listed deposit money banks in Nigeria using two models. The first model is a price model with market price per share, book value of equity per share, earnings per share and cash flow per share as proxies while the second model is a return model which has earning per share as proxies. The result of the two models indicated that adoption of IFRS improved relevance of accounting numbers in the deposit money banking sector. Umoren and Enang (2015) investigated the effect of IFRS adoption on the quality of accounting information of twelve listed banks in Nigeria from 2010 to 2014. The result from ordinary least square regression analysis indicated that the equity value and earnings of banks are relatively value relevant to share prices under IFRS than under the previous Nigerian SAS. Results also indicate that earnings per share is incrementally value relevant during post-IFRS period while book value of equity per share is incrementally less value relevant during the post-IFRS period.

Kargin (2013) studied the value relevance of accounting information in pre- and post-financial periods of International Financial Reporting Standards (IFRS) application for Turkish listed firms from 1998 to 2011 using the Ohlson model, the results show that value relevance of accounting information has improved in the post-IFRS period (2005-2011) considering book values while improvements have not been observed in value relevance of earnings. Onalo, Lizam, Kaseri and Innocent (2014) examined the IFRS and quality of financial statement information using earnings management, timeliness of loss recognition and value relevance. The study concludes that IFRS adoption engenders higher quality of banks financial statement information compared to local GAAP. Clarkson, Hanna, Richardson and Thompson (2011) examined the impact of IFRS adoption in Europe and Australia on the relevance of book value and earnings for equity valuation. With the aid of linear pricing models, on a sample of 3,488 firms that initially adopted IFRS in 2005, the study compared the figures originally reported for the 2004 fiscal year to the IFRS figures that were provided in 2005 as the 2004 IFRS comparative figures. As part of the inquiry, the study introduced a cross product term, equal to the product of EPS and BVPS into the traditional linear pricing models. The results revealed that estimated coefficient on the cross product term is negative and statistically significant. The results also revealed increased non-linearity in the data subsequent to IFRS adoption; with the increase being most pronounced for firms in common law countries.

Okafor and Ogiedu (2011) investigated the potential effects of the adoption and implementation of IFRS in Nigeria from the perspective of stakeholders using responses from questionnaires administered to a sample of accounting lecturers, auditors and accountants. Their results from Chi Square analysis revealed that IFRS have the potential for yielding greater benefits than current GAAP; improves business performance management and impacts on other business functions apart from financial reporting. The study also found that IFRS adoption will add to financial reporting complexities and increase compliance with accounting standards. Agostino, Drago and Silipo (2011) studied value relevance of book value and earnings for 221 listed banks from 15 EU countries from 2000 to 2006 resulting in 1201 observations. Using regression analyses on a multiplicative interactive model, of which partial effect of earnings and book value are conditional on IFRS adoption. The study found that book value was insignificant pre IFRS but negatively significant post IFRS while earnings has positive impact on share price of pre and post IFRS.

Nwaobia, Ogundajo, and Kwarbai (2016) investigated the value relevance of accounting information of companies listed on the Nigerian stock exchange (NSE) using modified Ohlson model and ten firms were selected from the 28 listed firms under the consumer goods sector. Content analysis was used to measure the qualitative values of accounting information (relevance, faithful representation, understandability, comparability and timeliness). The findings showed 
that there is no significant difference between the value relevance of accounting information prior and after the adoption of IFRS. Alabede (2016) studied the impact of IFRS adoption on the value relevance of accounting information of Nigerian listed companies. The study used sample of 67 non- financial companies operating in different sectors of the Nigerian economy and listed on Nigerian Stock Exchange (NSE) covering the period between 2007 and 2014, applied both return and price models to determine and compare the value relevance of accounting information in the pre and post IFRS adoption period. The findings under both models indicate that accounting information is more value relevant in post IFRS period but not significantly different from the pre IFRS period at least for the non-financial firms.

Suadiye (2012) examined empirically the impact of IFRS on the value relevance of accounting information in Turkey. Using the equity valuation model as suggested by Ohlson (1995), firstly, the value relevance of earnings and book values of equity produced under Turkish Local Standards (during 2000-2002) and under IFRS (during 2005-2009) is analyzed. The results revealed that earnings and book value are, jointly and individually, positively and significantly related to stock price under the two different reporting regimes. When two different reporting standards are compared, it is found that the adoption of IFRS increased the value relevance of accounting information in Turkish listed firms. Arum (2013) examined the impact of the mandatory implementation of IFRS on the quality of financial statement information in 117 companies listed in Indonesia Stock Exchange. The empirical results from multiple linear regression and logistic regression indicated that the implementation of IFRS has an effect to decrease the extent of earnings management and therefore, increase the value relevance of accounting information, but has no significant effect to increase the timely loss recognition.

\section{Area Description}

The study employed correlational research design in examining IFRS adoption and value relevance of financial information of quoted healthcare firms in Nigeria. Historical data of earnings and book value were collected from annual reports and regressed on the consequent stock prices. The population of the study consists of eleven healthcare firms quoted on the Nigerian stock exchange (NSE) as at 31st December, 2015. Six quoted healthcare firms were sampled out of the population on the basis of

i) Healthcare firms that were in existence and quoted as at 31 December 2015,

ii) Healthcare firms that have translated their financial information to IFRS from 2012, and

iii) Healthcare firms that have their complete information online.

Historical data of earnings per share (EPS), change in earnings (CEPS) and book value per share (BVPS) were collected from annual report and accounts available on firms' website. Also, share price (SP) data were collected from data base of Cashcraft asset management. The data of EPS, CEPS and BVPS were collected for the period of four years before IFRS adoption (2008-2011) and four years after IFRS adoption (2012-2015).

In order to find the value relevance of IFRS adoption in the healthcare firms EBO model was adopted. EBO model is a price model developed by Edward, Bells and Ohlson in 1995. EBO model was used because it is consistent with the definition of value relevance that assumes market value of equity reflects all publicly available and relevant information. The model relies on the "clean surplus accounting" relation, in which the intrinsic value of a firm can be expressed as original investment (original book value) plus the present value of infinite abnormal earnings beyond that investment. To be able to conduct the regression analyses, the following models using EBO model (Ohlson 1995) have been formulated:

$$
\begin{aligned}
S P_{i t}= & 0+\beta 1 E P S_{i t p r e}+\beta 2 C E P S_{i t p r e}+\beta 3 B V P S_{i t p r e}+e_{i t} \\
& S P_{i t}=0+\beta 1 E P S_{\text {itpost }}+\beta 2 C E P S_{\text {itpost }}+\beta 3 B V P S_{\text {itpost }}+e_{i t}
\end{aligned}
$$

Where:

$\mathrm{SP}_{\mathrm{it}}=$ the share price of healthcare firms ninety days after the financial year end.

$\mathrm{EPS}_{\mathrm{it}}=$ earnings per share of firm $\mathrm{i}$ at time $\mathrm{t}$.

$\mathrm{CEPS}_{\mathrm{it}}=$ change in earnings of firm $\mathrm{i}$ at time $\mathrm{t}$.

BVPS $_{\mathrm{it}}=$ book value per share of firm $\mathrm{i}$ at time $\mathrm{t}$.

$\mathrm{e}_{\mathrm{it}}=$ other variables that affect stock price.

\subsection{Measurement of Variables}

Share price is the dependent variable for this study and it is the amount at which the share of a firm listed on stock exchange market can be acquired at a particular point in time (ninety days after the financial year end of each year of study). The independent variables for this study are earnings per share, change in earnings per share (CEPS) and book value per share. EPS is calculated by dividing the net profit or loss of the period attributable to shareholders by the 
weighted average number of ordinary shares outstanding. Change in earnings is directly derived from earnings and it is calculated by subtracting the earnings of the previous year from that of the present year, then divided by the weighted average number of ordinary shares outstanding. BVPS is calculated by subtracting total liability from total assets which give the shareholders fund and then divided by the weighted average number of ordinary shares outstanding.

\section{Methods}

The study adopted Edward, Bells \& Olhson (EBO) model in order to make inference on value relevance of pre and post IFRS adoption of the quoted healthcare firms. EPS, CEPS and BVPS are the independent variables in the study while share price is the dependent variable. The study analyzed these set of variables each for pre IFRS and Post IFRS. Multiple regression analyses was employed to analyze the panel data using Statistical Package for Social Sciences (SPSS). Other supportive analyses were carried out like descriptive statistics which provided information on mean, standard deviation, minimum and maximum values in the set of data that were analyzed. Also, the correlation matrix results were produced in order to understand the interrelationship between variables.

\section{Results}

Table 1. The Descriptive Statistics of the Data for the year Pre IFRS Adoption Period 2008 to 2011

\begin{tabular}{llllll}
\hline & $\mathrm{N}$ & Minimum & Maximum & Mean & Std. Deviation \\
\hline SP & 24 & .67 & 26.00 & 7.1371 & 7.79845 \\
EPS & 24 & -1.14 & 2.79 & .3100 & .91185 \\
CEPS & 24 & -3.89 & 1.49 & -.0383 & .91923 \\
BVPS & 24 & .78 & 9.31 & 3.2725 & 1.84235 \\
Valid N (listwise) & 24 & & & & \\
\hline
\end{tabular}

Source: SPSS Output, 2018.

* SP=Share Price, EPS=Earnings per Share, CEPS=Change in Earnings per Share BVPS=Book Value per Share

The result in table 1 shows the mean, maximum, minimum and standard deviation for all the variables. Specifically the SP has a minimum value of 0.67 and a maximum value of 26.00, on average, SP has a mean of 7.1371 with a standard deviation of 7.79845. The same pattern of result is available for the other variables (EPS, CEPS and BVPS) as seen from table 1 . The results in table 1 have revealed that the share price, earnings per share, change in earnings per share and book value per share of the quoted healthcare firms vary a great deal from one firm to the other firm.

Table 2. The Descriptive Statistics of the Data for the year Post IFRS Adoption Period 2012 to 2015

\begin{tabular}{llllll}
\hline & $\mathrm{N}$ & Minimum & Maximum & Mean & Std. Deviation \\
\hline SP & 23 & .69 & 70.00 & 9.5687 & 18.48346 \\
EPS & 24 & -1.54 & 3.05 & .1933 & 1.11341 \\
CEPS & 24 & -1.18 & .32 & -.1696 & .40518 \\
BVPS & 24 & .74 & 13.35 & 4.6142 & 3.74706 \\
Valid N (listwise) & 23 & & & & \\
\hline
\end{tabular}

Source: SPSS Output, 2018.

Table 2 displays the mean, maximum, minimum and standard deviation for all the variables. Specifically the SP has a minimum value of 0.69 and a maximum value of 70.00, on average, SP has a mean of 9.5687 with a standard deviation of 18.48346. The same pattern of result is available for the other variables (EPS, CEPS and BVPS) as seen from table 2. From the result, it can be observed that the share price, earnings per share, change in earnings per share and book value per share of the quoted firms vary a great deal from one firm to the other firm.

Table 3. Correlation results of the data for the year Pre IFRS Adoption Period 2008 to 2011

\begin{tabular}{llllll}
\hline & & SP & EPS & CEPS & BVPS \\
\hline SP & Pearson Correlation & 1 & $.772^{* * *}$ & .217 & $.640^{* * *}$ \\
& Sig. (2-tailed) & & .000 & .308 & .001 \\
& N & 24 & 24 & 24 & 24 \\
EPS & Pearson Correlation & $.772^{* *}$ & 1 & .263 & $.801^{* *}$ \\
& Sig. (2-tailed) & .000 & & .215 & .000 \\
& $\mathrm{~N}$ & 24 & 24 & 24 & 24 \\
CEPS & Pearson Correlation & .217 & .263 & 1 & .033 \\
& Sig. (2-tailed) & .308 & .215 & & .878 \\
& $\mathrm{~N}$ & 24 & 24 & 24 & 24 \\
BVPS & Pearson Correlation & $.640^{* *}$ & $.801^{* *}$ & .033 & 1 \\
& Sig. (2-tailed) & .001 & .000 & .878 & \\
& $\mathrm{~N}$ & 24 & 24 & 24 & 24 \\
\hline
\end{tabular}


Source: SPSS Output, 2018

**. Correlation is significant at the 0.01 level (2-tailed).

Table 3 indicates the relationship between the variables used for pre IFRS adoption analysis. The relationship between SP, EPS, CEPS and BVPS is positive and significant at 0.772, 0.217 and 0.640 , this means that SP increases with the increase in EPS, CEPS and BVPS or vice versa. This is actually expected as a firm with high earnings is supposed to have a high price for its shares, EPS, CEPS and BVPS. Generally, the correlation matrix table revealed the likely presence of multi-collinearity among variable as the variables are highly correlated to the other so, there is no incidence of multi-collinearity.

Table 4. Correlation results of the data for the year Post IFRS Adoption Period 2012 to 2015

\begin{tabular}{llllll}
\hline & & SP & EPS & CEPS & BVPS \\
\hline SP & Pearson Correlation & 1 & $.882^{* *}$ & -.135 & $.876^{* *}$ \\
& Sig. (2-tailed) & & .000 & .529 & .000 \\
& $\mathrm{~N}$ & 24 & 24 & 24 & 24 \\
EPS & Pearson Correlation & $.882^{* * *}$ & 1 & .073 & $.736^{* *}$ \\
& Sig. (2-tailed) & .000 & & .733 & .000 \\
& $\mathrm{~N}$ & 24 & 24 & 24 & 24 \\
CEPS & Pearson Correlation & -.135 & .073 & 1 & -.337 \\
& Sig. (2-tailed) & .529 & .733 & & .107 \\
& $\mathrm{~N}$ & 24 & 24 & 24 & 24 \\
BVPS & Pearson Correlation & $.876^{* *}$ & $.736^{* *}$ & -.337 & 1 \\
& Sig. (2-tailed) & .000 & .000 & .107 & \\
& $\mathrm{~N}$ & 24 & 24 & 24 & 24 \\
\hline
\end{tabular}

Source: SPSS Output, 2018

Table 4 indicates the relationship between the variables used for pre IFRS adoption analysis. The relationship between SP, EPS and BVPS is positive at 0.882, and 0.876, this means that SP increases EPS, and BVPS or vice versa. This is actually expected as a firm with high earnings is supposed to have a high price for its shares, EPS, and BVPS. SP is negatively correlated to CEPS with a coefficient of -0.135 . It therefore, suggests that an increase in SP results to decrease in change in earnings of the quoted firms. Generally, the correlation matrix table revealed the likely presence of multi-collinearity among variable as the variables is highly correlated to the other so, there is no incidence of multi-collinearity.

Table 5. Summary of Regression Results

\begin{tabular}{lllll}
\hline Statistical Indicators & PRE & P-value & POST & P-value \\
\hline $\mathrm{R}^{2}$ & 0.597 & & 0.890 & \\
$\mathrm{R}$ & 0.773 & & 0.943 & \\
Adjusted $\mathrm{R}^{2}$ & 0.537 & & 0.873 & \\
$\mathrm{DW}$ & 1.064 & & 1.399 & \\
$\mathrm{~F}$ & 7.551 & & 53.861 & \\
Sig & 0.013 & & 0.00 & \\
EPS & 6.017 & 0.013 & 8.527 & 0.001 \\
CEPS & 0.251 & 0.850 & -0.393 & 0.924 \\
BVPS & 0.318 & 0.766 & 2.368 & 0.002 \\
\hline
\end{tabular}

Source: SPSS Output, 2018

Table 5 discussed the regression results in relation to IFRS adoption and value relevance of financial information of quoted Healthcare Firms in Nigeria for the period under review.

\subsection{Pre-Adoption Regression Result}

The result in table 5 shows that the co-efficient of the regression which is $\mathrm{R}^{2}$ is relatively above average at $59.7 \%$. This means that $59.7 \%$ of SP is explained by the explanatory variables (EPS, CEPS and BVPS) while $40.3 \%$ is unexplained. The Durbin Watson (DW) statistics of 1.064 suggests that the residuals of the variables are positively auto correlated at the $5 \%$ level of significance. This indicates that there is a positive autocorrelation among the error term of each of the variables used in this study. The result further showed that the model formulated is of good fit because the F-statistics as presented in the table is 7.551 which is significant at $5 \%$ because the p-value is less than 0.05 i.e. $0.013<0.05$. 
From the table the result showed that EPS has positive impact on share price and significant at $5 \%$ with a coefficient of 6.017, and p- value of 0.013. This implies that for every 5\% increase in EPS, there is a corresponding $6.017 \%$ increase in share price holding all other variables constant. The result showed that EPS has a positive significant impact on share prices thus, value relevant. More so, the coefficient for CEPS reveals a positive but insignificant relationship between CEPS and SP. It showed a coefficient of 0.251 and p-value of 0.850 . The implication is that for every $5 \%$ increase in CEPS, the SP increases by $0.251 \%$. The coefficient for BVPS reveals a significant positive impact on share prices since the coefficient is 0.318 , and p-value is 0.766 . This implies that for every $5 \%$ increase in BVPS there is a resulting $0.318 \%$ increase in share price. By implication, share price increases with increase in BVPS holding all other variables constant and it has a statistical significance thus, value relevant.

\subsection{Post Adoption Regression Result}

The result above showed that the co-efficient of the regression which is $\mathrm{R}^{2}$ is high at $89.0 \%$. This means that $89.0 \%$ of SP is explained by the explanatory variables (EPS, CEPS and BVPS) while $11.0 \%$ is unexplained. The Durbin Watson (DW) statistics of 1.399 suggests that the residuals of the variables are positively auto correlated at the $5 \%$ level of significance. This indicates that there is a positive autocorrelation among the error term of each of the variables used in this study. The result further showed that the model formulated is of good fit because the F-statistics as presented in the table is 53.861 which is significant at $5 \%$ because the p-value is less than 0.05 i.e. $0.00<0.05$.

The result showed that EPS has positive impact on share price and significant at $5 \%$ with a coefficient of 8.527, and pvalue of 0.01 . This implies that for every $5 \%$ increase in EPS, there is a corresponding $8.527 \%$ increase in share price holding all other variables constant. The result showed that EPS has a positive significant impact on share prices thus, value relevant. Moreover, the coefficient for CEPS revealed a negative and insignificant relationship between CEPS and SP. It showed a coefficient of -0.393 and p-value of 0.924 . The implication is that for every $5 \%$ increase in CEPS, the SP decreases by $0.393 \%$. But we expect that CEPS should have positive impact on SP if earnings consistently increased with increase in years.

The coefficient for BVPS revealed a significant positive impact on share prices since the coefficient is 2.368 , and $\mathrm{p}$-value is 0.02 . This implies that for every $5 \%$ increase in BVPS there is a resulting $2.368 \%$ increase in share price. By implication, share price increases with increase in BVPS holding all other variables constant and it has a statistical significance thus, value relevant. The relative value relevance can be ascertained by comparing the $R-$ squared $\left(R^{2}\right)$ of accounting information involved in the analyses. This study reveals Pre IFRS R-squared to be 0.597 while post IFRS $\mathrm{R}$-squared is 0.89 .

\section{Discussion}

The findings of the study are discussed as follows:

1. The result shows that EPS has a positive significant impact on share prices thus, value relevant during the Pre IFRS adoption period. This result goes in line with the findings of Alfaraih \& Alanezi (2011), Agostino, Drago \& Silipo (2011), Chalmers, Clinch \& Godfrey (2011), and Kargin (2013) who documented that EPS has positive significant impact on share price while it contradicts the findings of Chang, Su, Chen \& Chang (2008) and Khanagha, Mohamad, Hassan \& Sori (2011) who both found that EPS has positive insignificant relationship with share price.

2. The results also revealed that book value per share has a significant positive relationship with share price in the Pre IFRS adoption period. This implies share price increases with increase in book value per share thus the book value per share is value relevant. This result confirms findings of Kargin (2013), Alfaraih \& Alanezi (2011) and Khanagha (2011) who found that book value per share has positive significant impact on share price.

3. The findings of this study revealed that EPS has a positive significant impact on share prices thus, EPS is value relevant in the Post IFRS adoption period. This implies that EPS after IFRS adoption is value relevant. This result confirms the findings of Yahaya, Onyabe \& Usman (2015); Agostino, Drago \& Silipo (2011), Alfaraih \& Alanezi (2011), Kargin (2013), Chalmers, Clinch \& Godfrey (2011), and Khanagha (2011) and Umoren \& Enang (2015) whose findings showed that EPS is incrementally value relevant during post-IFRS period while it contradicts the findings of Kargin (2013) who opined that EPS based on IFRS has an insignificant effect on share price.

4. Share price increases with increase in BVPS holding all other variables constant and it has a statistical significance thus, value relevant during the Post IFRS adoption period. This finding confirms the general notion that if net asset is close to its realistic value it is value relevant and the findings of Agostino, Drago \& Silipo (2011), Alfaraih \& Alanezi (2011), Dung (2010), and Kargin (2013) While it contradicts the result of Chalmers, Clinch \& Godfrey (2011). The result also contradicts the statement of Burgstahler \& Dichev (1997) 
that the extent of association of earnings and book value is dependent on the level of success of a firm, because when a firm is unsuccessful book value becomes an important determinant of equity value.

5. The overall results revealed that post IFRS financial information have relative value relevance over and above pre IFRS financial information. The finding of this study confirms the outcome of Kargin (2013), while it contradicts the findings of Khanagha (2011).

\section{Conclusion}

A high quality accounting is expected to make financial information to reflect the changes in stock price i.e. explaining a reasonable part of variation in stock price. A change in accounting and financial reporting should mean an improvement over the previously existing standard. In the light of these findings, the study concludes that Pre IFRS financial information is value relevant and Post IFRS financial information is also value relevant. The study further concludes that Post IFRS financial information is more value relevant than the Pre IFRS financial information. Therefore, accounting information has value relevance and IFRS adoption has pronounced impact in the Nigeria Healthcare Sector. The study then specifically concludes that EPS before and after IFRS adoption has positive impact on stock price and as such could be a basis for making market decisions. Therefore EPS before and after IFRS is value relevant. The study also concludes that CEPS before and after IFRS adoption has no significant impact on share price and as such they are not value relevant. Book value per share VPS before and after IFRS adoption has positive significant impact on stock price. Thus, BVPS before and after IFRS adoption is value relevant.

\section{References}

Agostino, M., Drago, D., \& Silipo, D. B. (2011). The value relevance of IFRS in the European banking industry. Review of Quantitative Finance and Accounting, 36(3), 437-457. https://doi.org/10.1007/s11156-010-0184-1

Alabede, J. O. (2016). Impact of accounting standards on the value relevance of accounting information from Nigeria's listed firms: Comparative Study of Pre and Post IFRS Adoption. Paper presented at the international conference organised by the Department of Management and Accounting, Obafemi Awolowo University, Ile Ife, Nigeria. $\begin{array}{lllll}\text { Retrieved on } & \text { March } & 2017 & \text { from }\end{array}$ https://www.researchgate.net/profile/James_Alabede/publication/304541195.pdf.

Alfaraih, M., \& Alanezi, F. (2011). The usefulness of earnings and book value for equity valuation to Kuwait stock exchange participants. The International Business \& Economics Research Journal, 10(1), 73. https://doi.org/10.19030/iber.v10i1.929

Arum, E. D. P. (2013). Implementation of international financial reporting standards (IFRS) and the quality of financial statement information in Indonesia. Research Journal of Finance and Accounting, 4(19), 200-209.

Barth, M. E., Beaver, W. H., \& Landsman, W. R. (2001). The relevance of the value relevance literature for financial accounting standard setting: another view. Journal of accounting and economics, 31(1-3), 77-104. https://doi.org/10.1016/S0165-4101(01)00019-2

Beisland, L. A. (2009). A review of the value relevance literature. The Open Business Journal, 2(1), 7-27. https://doi.org/10.2174/1874915100902010007

Burgstahler, D. C., \& Dichev, I. D. (1997). Earnings, adaptation and equity value. Accounting review, 72(2), 187-215.

Chalmers, K., Clinch, G., \& Godfrey, J. M. (2011). Changes in value relevance of accounting information upon IFRS adoption: Evidence from Australia. Australian Journal of Management, 36(2), 151-173. https://doi.org/10.1177/0312896211404571

Chang, H. L., Chen, Y. S., Su, C. W., \& Chang, Y. W. (2008). The relationship between stock price and EPS: Evidence based on Taiwan panel data. Economics Bulletin, 3(30), 1-12.

Chebaane, S., \& Othman, H. B. (2014). The impact of IFRS adoption on value relevance of earnings and book value of equity: The case of emerging markets in African and Asian regions. Procedia-Social and Behavioral Sciences, 145, 70-80. https://doi.org/10.1016/j.sbspro.2014.06.012

Clarkson, P., Hanna, J. D., Richardson, G. D., \& Thompson, R. (2011). The impact of IFRS adoption on the value relevance of book value and earnings. Journal of Contemporary Accounting \& Economics, 7(1), 1-17. https://doi.org/10.1016/j.jcae.2011.03.001

Edwards, E. O., \& Bell, P. W. (1961). The theory and measurement of business income ( $7^{\text {th }}$ ed.). University of California Press, Berkeley, London. 
Fodio, M. I., \& Salaudeen, Y. M. (2012). Comparative analysis of the value relevance of historical cost accounting and inflation-adjusted accounting information. International Journal of Economics and Management sciences, 1(8), 25-33.

Francis, J., \& Schipper, K. (1999). Have financial statements lost their relevance? Journal of accounting Research, 37(2), 319-352. https://doi.org/10.2307/2491412

Ikpefan, O. A., \& Akande, A. O. (2012). International financial reporting standard (IFRS): Benefits, obstacles and intrigues for implementation in Nigeria. Business Intelligence Journal, 5(2), 299-307.

Kaaya, I. D. (2015). The International Financial Reporting Standards (IFRS) and Value Relevance: A Review of Empirical Evidence. Journal of Finance and Accounting. 3(3), 37-46.

Kargin, S. (2013). The impact of IFRS on the value relevance of accounting information: Evidence from Turkish firms. International Journal of Economics and Finance, 5(4), 71. https://doi.org/10.5539/ijef.v5n4p71

Keener, M. H. (2011). The relative value relevance of earnings and book value across industries. Journal of Finance and Accountancy, 6(12), 99-122.

Khanagha, J. B. (2011). International Financial Reporting Standards (IFRS) and value relevance of accounting information: evidence from Bahrain and United Arab Emirates stock markets. African Journal of Social Sciences, l(1), 101-114.

Khanagha, J. B., Mohamad, S., Hassan, T., \& Sori, Z. M. (2011). The impact of reforms on the value relevance of accounting information: Evidence from Iran. African Journal of Business Management, 5(1), 96.

Kirkulak, B., \& Balsari, C. K. (2009). Value relevance of inflation-adjusted equity and income. The International Journal of Accounting, 44(4), 363-377. https://doi.org/10.1016/j.intacc.2009.09.007

Kousenidis, D. V., Ladas, A. C., \& Negakis, C. I. (2010). Value relevance of accounting information in the pre-and post-IFRS accounting periods. European Research Studies, 13(1), 143.

Lee, E., Walker, M., \& Zeng, C. (2013). Does IFRS convergence affect financial reporting quality in China? ACCA research report, 131.

Mamuda, M. U. (2015). Value relevance of accounting information in the Nigerian listed Conglomerate Firms.

Nwaobia, A., Ogundajo, G., \& Kwarbai, J. (2016). Value relevance of Accounting information and firm value: A Study of consumer goods manufacturing sector in Nigeria. European Journal of Business and Management, 8(24), 107-124.

Ohlson, J. A. (1995). Earnings, book values, and dividends in equity valuation. Contemporary Accounting Research, 11(2), 661-687. https://doi.org/10.1111/j.1911-3846.1995.tb00461.x

Okafor, C., \& Ogiedu, K. O. (2011). Potential effects of adoption and implementation of IFRS in Nigeria. JORIND, 9(2), 345-358.

Onalo, U., Lizam, M., Kaseri, A., \& Innocent, O. (2014). International Financial Reporting Standards and the Quality of Banks Financial Statement Information: Evidence from an Emerging Market-Nigeria. World Academy of Science, Engineering and Technology, International Journal of Economics and Management Engineering, 1(12).

Onisanwa, I. D. (2014). The impact of health on economic growth in Nigeria. Journal of Economics and Sustainable Development, 5(19), 159-166.

Outa, E. R. (2011). The impact of International Financial Reporting Standards (IFRS) adoption on the accounting quality of listed companies in Kenya. International Journal of Accounting and Financial Reporting, 1 (1), 212-241. https://doi.org/10.5296/ijafr.v1i1.1096

Paananen, M., \& Lin, H. (2009). The development of accounting quality of IAS and IFRS over time: The case of Germany. Journal of International accounting research, 8(1), 31-55. https://doi.org/10.2308/jiar.2009.8.1.31

Suadiye, G. (2012). Value Relevance of Book Value \& Earnings under the Local GAAP and IFRS: Evidence from Turkey/Yerel Muhasebe Standartlarina ve UFRS'ye Göre Hazirlanan Kar ve Özkaynak Rakamlarinin Hisse Senedi Fiyatlarina Yansimasi: Türkiye Örnegi. Ege Akademik Bakis, 12(3), 301. Retrieved March 4, 2016 from https://search.proquest.com/openview/13ba5363332898ca1972e3096b211fc9/1?pq-origsite=gscholar\&cbl=136110

Talebnia, G. A., Valipour, H., \& Askari, Z. (2012). Effect of free cash flow agency on the value relevance of earnings per share and book value per share with stock price in the chemical and medical industries: Evidence from Tehran stock exchange. American Journal of Scientific Research, 46, 118-127. 
Umoren, A. O., \& Enang, E. R. (2015). IFRS adoption and value relevance of financial statements of Nigerian listed banks. International Journal of Finance and Accounting, 4(1), 1-7.

Yahaya, O. A., Onyabe J. M., \& Usman, S. O. (2015). International financial reporting standards' adoption and value relevance of accounting information of listed deposit money banks in Nigeria. Journal of Economics and Sustainable Development 6(12), 85-93

Zeng, X., Guo, X., Yang, C. T., \& Xiong, Y. (2012). Value relevance of financial assets' fair values: Evidence from Chinese listed companies. African Journal of Business Management, 6(12), 4445.

\section{Copyrights}

Copyright for this article is retained by the author(s), with first publication rights granted to the journal.

This is an open-access article distributed under the terms and conditions of the Creative Commons Attribution license which permits unrestricted use, distribution, and reproduction in any medium, provided the original work is properly cited. 